УДК 331.5

JEL Classification: H53; I38; M14

ДРУЖИНІНА В. В. ${ }^{1}$, ЛУЦЕНКО Г. П. ${ }^{2}$, РОМАНЮК Б. Ф. ${ }^{3}$

\title{
СУТНІСТЬ ПОНЯТТЯ «ІНВАЛІДНІСТЬ» В ПЕРСПЕКТИВІ СОЦАЛЬНО-ТРУДОВОЇ ІНКЛЮЗІї
}

DOI: $10.32620 /$ cher.2021.1.02

Постановка проблеми: В умовах фінансово-економічної кризи, військових конфліктів, дефіциту державного бюджету, загострюється проблема соціального захисту осіб з інвалідністю. Сучасна соціальна політика орієнтована на забезпечення рівності прав і можливостей в реалізації потенційної здатності та індивідуальних ресурсів кожного члена суспільства. Актуальність даної теми обумовлена незмінно високим числом осіб з інвалідністю та відсутністю цілісного підходу до вирішення проблем, пов’язаних з інвалідністю, що у свою чергу викликало необхідність аналізу теоретичних підходів до визначення сутнісних характеристик ряду понять. Мета дослідження - узагальнити теоретичні підходи і положення з питань сутності поняття «інвалідність» в перспективі соціально-трудової інклюзії. Предметом дослідження є теоретичні аспекти та сучасний стан розвитку поняття «інвалідність» в перспективі соціально-трудової інклюзії. Методи дослідження: методологічну базу дослідження склали наукові досягнення вітчизняних та зарубіжних вчених при розкритті змістовного навантаження понять. Гіпотеза дослідження. Припущено, що в основу соціальнотрудової інклюзії має бути покладено сукупність теоретичних засад, історичних передумов та сучасних обставин розвитку наукового поняття «інвалідність» під впливом соціально-культурних, історичних та географічних факторів, а також рівня знань про суспільство та його домінуючими цінностями. Виклад основного матеріалу. У результаті дослідження даного питання було розглянуто основні підходи та альтернативні погляди вітчизняних і зарубіжних авторів щодо визначення поняття «інвалід», «інвалідність», «інвалідизація», «стигматизації», представлено концепцію повноцінної інтеграції інвалідів в суспільство та основні бар'єри пов'язані з інвалідністю. Оригінальність та практична значимість дослідження: представлені у дослідженні наукові підходи щодо визначення дефініцій поняття «інвалідність» з урахуванням просування їх до суспільства. Висновки та перспективи подальших досліджень: Необхідно вживати рішучі спільні дії усіх органів самоврядування, установ соціального захисту разом із закладами охорони здоров'я, неурядовими організаціями та роботодавцями, що дозволить запобігти інвалідності, а також професійно активізувати інклюзивних осіб у нашій країні . Ефективна система повинна включати комплексну реабілітацію, розпочату на найранішій стадії захворювання, щоб іiї ефективність була якомога більшою.

Ключові слова:

інвалід, інвалідність, інвалідизація, стигматизація, особи з обмеженими можливостями, ринок праці.

\section{THE ESSENCE OF THE CONCEPT OF "DISABILITY" IN THE PERSPECTIVE OF SOCIAL AND LABOR INCLUSION}

${ }^{1}$ Дружиніна Вікторія Валеріївна, д-р екон. наук, професор, професор кафедри бізнес адміністрування, марке тингу і туризму, Кременчуцький національний університет ім. Михайла Остроградського, м. Кременчук, Україна.

Druzhynina Viktoriia, Doctor of Economic Science, Professor, Professor of the Business Administration, Marketing and Tourism Department, Kremenchuk Mykhailo Ostrohradskyi National University, Kremenchuk, Ukraine.

e-mail: drughinina.vd@gmail.com

ORCID ID: 0000-0001-8776-1408

2 Луценко Галина Павлівна, викладач-методист вищої категорії циклової комісії економіки та управління, Кременчуцький льотний коледж Харківського національного університету внутрішніх справ, м. Кременчук, Україна.

Lutsenko Galyna, teacher-methodologist of the highest category of the cycle commission of economics and Management, Kharkiv National University of Internal Affairs Kremenchuk flight college, Kremenchuk, Ukraine.

e-mail: lucenkogalina1952@gmail.com

ORCID ID: 0000-0002-2628-5521

${ }^{3}$ Романюк Богдан Федорович, студент спеціальності 242 «Туризм», Кременчуцький національний університет ім. Михайла Остроградського, м. Кременчук, Україна.

Romaniuk Bogdan, student of 242 Tourizm, Kremenchuk Mykhailo Ostrohradskyi National University, Kremenchuk, Ukraine.

e-mail: bogdan.romaniuk99@gmail.com

ORCID ID: 0000-0002-5740-8571 
Problem statement. In the conditions of financial and economic crisis, military conflicts, state budget deficit, the problem of social protection of persons with disabilities is exacerbated. Modern social policy is focused on ensuring equal rights and opportunities in the realization of the potential capacity and individual resources of each society member. The relevance of this topic is due to the consistently high number of people with disabilities and the lack of a holistic approach to solving problems related to disability, which in turn necessitated the analysis of theoretical approaches to determining the essential characteristics number of concepts. The purpose of the study - to summarize the theoretical approaches and provisions on the essence of the "disability" concept in the perspective of social and labor inclusion. The subject of the research is the theoretical aspects and the current development state of the "disability" concept in the perspective of social and labor inclusion. Research methods: the methodological basis of the study was the scientific achievements of domestic and foreign scientists in revealing the content of concepts. Research hypothesis it is assumed that the basis of socio-labor inclusion should be a set of theoretical principles, historical background and current circumstances of the scientific "disability" concept under the influence of socio-cultural, historical and geographical factors, as well as knowledge about society and its dominant values. Presentation of the main material. As a result of the study of this issue the main approaches and alternative views of domestic and foreign authors on the definition of "disabled", "disability", "disability", "stigmatization" were considered, the concept of full integration of disabled people into society and the main bar era related to disability. Originality and practical significance of the research. The research presents scientific approaches to defining the concept of "disability" taking into account their promotion in society. Conclusions and prospects for further research. It is necessary to take decisive joint action of all self-government bodies, social protection institutions together with health care institutions, nongovernmental organizations and employers, which will prevent disability and professionally inclusive people in our country. An effective system should include comprehensive rehabilitation initiated at the earliest stage of the disease to maximize its effectiveness.

Key words:

disability, disability, disability, stigmatization, persons with disabilities, labor market.

СУЩНОСТЬ ПОНЯТИЯ «ИНВАЛИДНОСТЬ» В ПЕРСПЕКТИВЕ СОЦИАЛЬНО-ТРУДОВОЙ ИНКЛЮЗИИ

Постановка проблемы. В условиях финансово-экономического кризиса, военных конфликтов, дефицита государственного бюджета, обостряется проблема социальной защиты лиц с инвалидностью. Современная социальная политика ориентирована на обеспечение равенства прав и возможностей в реализации потенциальной способности и индивидуальных ресурсов каждого члена общества. Актуальность данной темы обусловлена постоянно высоким числом людей с инвалидностью и отсутствием целостного подхода к решению проблем, связанных с инвалидностью, что в свою очередь вызвало необходимость проведения анализа теоретических подходов к определению сущностных характеристик понятий. Цель исследования - обобщить теоретические подходы и положения по вопросам сущности понятия «инвалидность» в перспективе социально-трудовой инклюзии. Предметом исследования являются теоретические аспекты и современное состояние развития понятия «инвалидность» в перспективе социально-трудовой инклюзии. Методы исследования: методологическую базу исследования составили научные достижения отечественных и зарубежных ученых при раскрытии смысловой нагрузки понятий. Гипотеза исследования: предположено, что в основу социально-трудовой инклюзии должен быть положен совокупность теоретических основ, исторических предпосылок и современных обстоятельств развития научного понятия «инвалидность» под влиянием социально-культурных, исторических и географических факторов, а также уровня знаний об обществе и его доминирующими ценностями. Изложение основного материала. В результате исследования данного вопроса были рассмотрены основные подходы и альтернативные взгляды отечественных и зарубежных авторов по определению понятия «инвалид», «инвалидность», «инвалидизация», «стигматизации», представлена концепция полноценной интеграции инвалидов в общество и основные баръеры связанные с инвалидностью. Оригинальность и практическая значимость исследования: представлены в исследовании научные подходы к определению дефиниций понятия «инвалидность» с учетом продвижения их к обществу. Bыводы и перспективы дальнейших исследований. Необходимо принимать решительные совместные действия всех органов самоуправления, учреждений социальной защиты вместе с учреждениями здравоохранения, неправительственными организациями и работодателями, что позволит предотвратить инвалидность, а также профессионально активизировать инклюзивных лиц в нашей стране. Эффективная система должна включать комплексную реабилитацию, начатую на ранней стадии заболевания, чтобы ее эффектив- 
ность была как можно больше.

\section{Ключевые слова:}

инвалид, инвалидность, инвалидизация, стигматизация, лица с ограниченными возможностями, рынок труда.

Постановка проблеми. Інвалідність являє собою соціальний феномен, уникнути якого не може не одне суспільство, и кожна держава згідно рівня свого розвитку, пріоритетів та можливостей формує соціальну та економічну політику по відношенню до людей $з$ інвалідністю. Інтеграція осіб з інвалідністю в суспільство $є$ їх невід'ємним цивільним правом та свобода праці виступає в якості одного 3 основоположних прав людини, адже основна частина населення забезпечує свої життєві потреби шляхом здійснення трудової діяльності, тому забезпечення рівності щодо праці і рівна плата за неї є основоположним пунктом соціально-економічної політики у всіх країнах світу. Фактично значна кількість людей з інвалідністю, які мали бажання працювати, в сучасних реаліях позбавлені доступу до реабілітації та можливості якісного працевлаштування. Враховуючи вище викладене актуальним $є$ більше детально розкрити характеристики різних наукових підходів стосовно осіб з обмеженими можливостями.

Аналіз останніх досліджень і публікацій. Поняття інвалідності формувалося століттями, ця еволюція в основному визначається соціально-культурними, історичними та географічними факторами, а також рівнем знань про суспільство та його домінуючими цінностями. У давнину хвороби та психічні розлади, а також деформації та фізичні вади розглядалися як покарання богів за гріхи, вчинені їхніми батьками або подальшими предками, перебуваючи у володінні злих сил або духів, передбаченні неминучої поразки або катастрофи. Тому люди 3 інвалідністю були витіснені на узбіччя громад, в яких вони жили. Беата Боровська-Бешта пише, що історично простежується неприйняття суспільством осіб з інтелектуальними вадами, боротьба 3 ними та створення жорстких умов життя для дітей-інвалідів, підлітків та дорослих. Такий підхід був домінуючим у Греції та Римі. У Стародавній Греції домінували позиції, що відзначали чорну пляму розвитку людства. Ці часи були сповнені браку знань, незнання та жорстокості щодо людей з обмеженими можливостями. Подібним чином, у Стародавньому Римі немовлят із видимими деформаціями вбивали, щоб врятувати суспільство від катастроф або полегшити соціальну тривогу.

Серйозність відхилення через деформацію чи інвалідність відрізнялася в різних частинах стародавнього світу завдяки традиціям та культурі громади. Найвідомішим і водночас рішучим прикладом є Спарта, де застосовувались євгенічні практики, а «відмова від хворих новонароджених навіть вимагалася законом». Афіни характеризувались набагато м'якшим підходом до інвалідності, де були організовані форми підтримки для тих, хто втратив повноту фізичної форми в результаті війни або на роботі. У країнах Далекого Сходу інвалідність трактувалася як боротьба між добром і злом або як порушення балансу між людиною та навколишнім середовищем (Китай, Японія) та як дар богів (Індія).

Наступні епохи відзначаються розвитком знань про інвалідність та форми навчання, розвитку, допомоги та підтримки. Однак це не означає, що асоціація інваліда 3 неповним або навіть непотрібним елементом суспільства була повністю ліквідована із соціальної свідомості. Поляризація поглядів у цій галузі є найкращою у 1930-х роках. В ті часи простежується як позитивне, наприклад розвиток освіти людей 3 обмеженими можливостями, поліпшення їх життєвих умов, так і негативне ставлення до таких категорій людей, використовуючи наукові концепції та соціальні рухи, наприклад, євгенічні теорії.

Інвалідність також по-різному сприймається сьогодні в соціальному та громадському просторі. Вирішенню теоретичних i практичних проблем, пов'язаних з питанням осіб з обмеженими можливостями та їх інтеграція у трудову діяльність присвятили свої праці такі вчені, як: Андрєєв В. С., Байда Л., Безпалько О. В., Гусак Н., Слахіна В. П., Артюх С. О., Котова Л. В., Лукашевич М. П., Мигович І. В., Похвощєв А. В., Чуксіна В. В., Шурма I.M. та інші. Незважаючи на поширення ідеї прав людини, розвиток суспільства в дусі співпереживання та розуміння інших, а також поваги до їх гідності та функціонування в законі про недискримінацію, негативні установки, пов'язані з соромом, нерозуміння, відсутність елементарних почуттів або не- 
знання суті інвалідності все ще часто з'являються в суспільстві.

Мета статті. Узагальнити теоретичні підходи і положення 3 питань сутності поняття «інвалідність» в перспективі соціальнотрудової інклюзії.

Виклад основного матеріалу дослідження. В нинішній час гострим питанням $\epsilon$ невпинне збільшення кількості осіб з обмеженими можливостями не тільки в нашій країні, але і у всьому світі. Така велика кількість людей 3 інвалідністю викликана різними причинами (війнами, катастрофами, нещасними випадками, погіршенням екологічних умов, небезпечними умовами праці та інше) які, безсумнівно, повинні враховуватися при формуванні законодавства, відповідно соціального захисту цієї категорії населення. Тривалий час до людей з обмеженими можливостями ставилися не так як до інших. В нинішній час відношення до них також відрізняється від відношення до тих людей, які відхилень не мають. Відсутність результативної системи соціального захисту залишило відбиток у свідомості багатьох людей з обмеженими можливостями, щодо своєї другорядності і неповноцінності. Що не тільки ображає гідність людини, але і обмежує можливість самозахисту. Проте, змінюються пріоритети та принципи побудови соціальної сфери, відношення до різноманітних соціальних груп та системи соціального захисту. При цьому особу з обмеженими можливостями слід розглядати не як пасивного отримувача допомоги та підтримки, в першу чергу, необхідно враховувати його життєву силу та енергію, індивідуальні, культурні та гендерні відмінності.

Аналіз розвитку проблеми інвалідності як соціального явища свідчить про те, що пройшовши шлях від ідеї ізольованості «неповноцінних» осіб суспільства до концепції їх залучення до трудової діяльності, людство підійшло до розуміння необхідності інтеграції осіб з обмеженими можливостями до суспільних інститутів. У зв'язку з чим питання обрало нову актуальність та викликало необхідність більш детально окреслити ключові поняття даної теми.

У науковій літературі існує достатня кількість визначень стосовно інвалідності, у наукових статтях була спроба їх класифікувати і узагальнити, тому доречно провести аналіз поширених тлумачень різноманітних ав- торів до визначення терміну «інвалід» та «інвалідність» (таблиця 1).

Таблиця 1 демонструє розмежування понять згідно медичного, соціального та економічного підходів. Медична (традиційна) модель передбачає, що інвалідність являє собою деякі відхилення від норми у зв'язку 3 порушенням здоров'я, викликано хворобою, травмою, що призвела до довгострокової, повної або часткової втрати працездатності. В медицині інвалід досить тривалий час розглядався в якості неповноцінної людини, внаслідок чого вважалося, що йому слід перебувати у спеціально утворених для цього умовах окремо від інших людей, при тому що рішення відносно його життя мають приймати спеціалісти в медичній області та реабілітації. Однак варто відзначити, що деякі фізичні недоліки не означають автоматичної неможливості до самореалізації особистості, відповідно, відсутні підстави для встановлення контролю над зазначеними особами або ж позбавлення їх можливості самостійно жити та розвиватися у суспільстві [10].

Соціальна модель, передбачає, що всі без винятку люди $€$ повноцінними, незалежно від стану їх здоров'я та наявності тих чи інших фізичних недоліків. Інвалідність виступає як деякий стан, за якого унаслідок порушень здоров'я особа зустрічається з певними соціальними бар'єрами при реалізації його здібностей і можливостей. Так, наприклад, М. Лукашевич та I. Мигович зазначають, що поняття «інвалід» увійшло з латинської мови «invalidus» у визначенні слабкої та немічної особи. Як правило, спочатку це поняття характеризувало нетиповий стан людини та мало безліч різноманітних відтінків, починаючи 3 особи «не 3 цього світу», яка $\epsilon$ презренною для суспільства, та особи, що функціонально непридатна до існування у суспільстві. Згодом трактування інвалідності набуло змін, що дало змогу не тільки відображати суспільне відношення, але й сформувати цілісний підхід до інвалідів, як до окремого соціального прошарку $[11,124]$.

О. В. Безпалько, І. В. Братусь та Т. Л. Лях зазначають, що інвалід - це особа, яка має порушення здоров'я зі стійкими розладами функцій організму, обумовлене захворюванням, наслідками травми чи дефектами, що призводять до обмеженої життєдіяльності, й потребує соціального захисту [7, с. 42]. 
Т а б л и ц я 1 - Дефініції поняття «інвалідність» згідно різних підходів

\begin{tabular}{|c|c|}
\hline Поняття & Джерело \\
\hline \multicolumn{2}{|l|}{ Медичний підхід } \\
\hline $\begin{array}{l}\text { Інвалідність є «стан організму людини, що характеризується постійною або } \\
\text { тривалою втратою професійної працездатності та значним обмеженням її» }\end{array}$ & {$[1$, c. 6$]$} \\
\hline $\begin{array}{l}\text { Інвалідність - це тривала або постійна втрата працездатності, що виникла } \\
\text { внаслідок хронічного захворювання або травми, що призвели до значного по- } \\
\text { рушення функцій організму }\end{array}$ & {$[2$, c. $7-8]$} \\
\hline $\begin{array}{l}\text { Інвалід це особи зі стійкими фізичними, психічними, інтелектуальними або } \\
\text { сенсорними порушеннями, які при взаємодії з різними бар'єрами можуть зава- } \\
\text { жати їхній повній та ефективній участі в житті суспільства нарівні з іншими }\end{array}$ & \multirow[t]{2}{*}[3]{} \\
\hline $\begin{array}{l}\text { Інвалідність - втрата або аномалія фізіологічної, психологічної або анатомі- } \\
\text { чної структури або функції }\end{array}$ & \\
\hline $\begin{array}{l}\text { Інвалідність - стан, при якому особа внаслідок хронічного захворювання } \\
\text { або анатомічних дефектів, що викликають стійке, незважаючи на лікування, } \\
\text { порушення функцій організму, вимушена припинити професійну діяльність на } \\
\text { тривалий термін або може працювати при значній зміні звичайних умов праці }\end{array}$ & {$[4$, c. 132$]$} \\
\hline \multicolumn{2}{|l|}{ Сочіальний підхід } \\
\hline $\begin{array}{l}\text { Інвалідність - «повну або часткову втрату громадянином здатності чи мож- } \\
\text { ливості здійснювати самообслуговування, самостійно пересуватися, орієнтува- } \\
\text { тися, спілкуватися, контролювати свою поведінку, навчатися або займатися } \\
\text { трудовою діяльністю }\end{array}$ & {$[5]$} \\
\hline $\begin{array}{l}\text { «Інвалідність - це перешкода чи обмеження активності, викликане сучасним } \\
\text { соціальним устроєм, яке приділяє незначне або не приділяє взагалі ніякої уваги } \\
\text { людям, які мають фізичні дефекти, і таким чином виключає їх участь в основ- } \\
\text { ній соціальній діяльності товариства }\end{array}$ & {$[6$, c. $46-48]$} \\
\hline $\begin{array}{l}\text { Інвалідність - це порушення здоров’я людини зі стійкими розладами функ- } \\
\text { цій організму, обумовлене захворюванням, наслідками травми чи дефектами, } \\
\text { що призводять до обмеженої життєдіяльності, й потребує соціального захисту }\end{array}$ & \\
\hline $\begin{array}{l}\text { Інвалідність - це специфічний соціальний феномен, що відображає дисфун- } \\
\text { кціональні порушення різноманітних суспільних відносин в системі «інвалід- } \\
\text { соціум», що характеризується відхиленням від норми у здоров'ї, обмеженням } \\
\text { життєдіяльності особистості в конкретному просторово-часовому континуумі, } \\
\text { а такжде наявністю особливих світосприйняття, світорозуміння, соціальних } \\
\text { інститутів, інакшість поведінки, що вимагає створення спеціальних медичних, } \\
\text { психологічних і соціальних умов. }\end{array}$ & {$[7$, c. 42$]$. } \\
\hline \multicolumn{2}{|l|}{ Економічний підхід } \\
\hline $\begin{array}{l}\text { Інвалідність - це нездатність підтримувати інвалідом економічну незалеж- } \\
\text { ність, яка веде до незалежності від оточуючих і (або) від держави }\end{array}$ & {$[8]$} \\
\hline $\begin{array}{l}\text { Інвалідність - тривала або постійна, повна або часткова втрата працездатно- } \\
\text { сті, причиною якої є стійкі або звротні порушення функцій організму, захво- } \\
\text { рювання, каліцтва або дефекти розвитку }\end{array}$ & [9] \\
\hline
\end{tabular}
Джерело: розроблено авторами

Л. В. Котова виокремлює поняття «інвалід» - як людину, що має особливий психіко-фізіологічний стан, який зумовлений захворюванням, травмою (iї наслідками) або вродженими вадами розумового чи фізичного розвитку, що призводить до обмеження нормальної життєдіяльності [12].

Слагін В. П. та Артюх С. О. під терміном «інвалід» вважається особа зі стійким розладом функцій організму, зумовленим захворюванням, наслідком травм або уродже- ними дефектами, що призводить до обмеження життєдіяльності, до необхідності в соціальній допомозі та захисті [13].

Великий тлумачний словник сучасної української мови пояснює, що інвалід - це людина, яка частково чи повністю втратила працездатність унаслідок поранення, хвороби, каліцтва чи старості, а інвалідність є станом інваліда [14, с. 397].

Що стосується поняття «інвалідність» так на думку Левчук Н. М. термін розгляда- 
ється як важлива характеристика стану здоров'я населення та окреслює ту межу, за якою травми, хвороби та інші порушення здоров'я обертаються стійким зниженням працездатності та звуженням «простору» життєдіяльності.

В сучасному трансформаційному суспільстві відбуваються позитивні зміни у ставлення до людей 3 інвалідністю. Аналізуючи понятійний апарат відносно людей з інвалідністю помічаємо, що він еволюціонує а також розширюються підходи до вивчення даного явища.

Так наприклад, Байда Л. визначає, що інвалідність - це соціальне явище, а не захворювання чи вирок. Інваліди не вимагають чогось особливого, лише елементарне - можливість жити серед людей, бути в суспільстві і відчувати себе людьми. Як доводить практика, люди 3 особливими потребами можуть бути і стають повноцінними членами суспільства, які надихають своїм прикладом багатьох, зокрема й абсолютно здорових людей [15].

Іпатов А. В та Ханюкова I. Я. зазначає, що інвалідність неможливо розглядати ізольовано від соціального і фізичного світу, який інколи $є$ причиною обмежень людей $з$ інвалідністю. Інвалідність - це наслідок середовища, що не відповідає можливостям людини.

Якщо розглядати інвалідність 3 точки зору економічного підходу, то до такої категорії людей належать особи, які не здатні або частково здатні брати участь в процесі виробництва, не здатні або частково здатні до продуктивної праці i, як наслідок, живуть на допомогу 3 інвалідності або на мінімальну заробітну плату. В результаті у людей з інвалідністю виникає велика кількість бар'єрів, що будує суспільство 3 різними поглядами стосовно людей 3 інвалідністю, наприклад, таких, як стигма та дискримінація: недостатня доступність послуг з охорони здоров'я та реабілітаційних послуг чи проблем доступності транспорту, приміщень та інформації.

Стигма поєднує знання, ідеологічні уявлення та емоційні компоненти. Стигма - це досить часто не просто страх невідомого характерний для кожної людини, а страх захворювання i, в кінцевому підсумку, смерті, усвідомлення власної незахищеності [16, с. 43]. Стигматизація представників даної соціальної групи означає необгрунтоване приписування їм негативних соціальних якостей до їхніх індивідуальних характеристик, виключно на основі групової належності.

Ще один термін, який потребує осмислення - «інвалідизація». На відміну від інвалідності, вживаючи термін «інвалідизація» маємо на увазі не окремий індивід та його проблеми, а взаємозв'язок людини і навколишнього середовища, вплив суспільства на життєдіяльність людини. Обмежені можливості розуміються як наслідок того, що соціальні та фізичні умови (культура суспільства, психологічний клімат, соціальна і політична організація тощо), у яких живе і працює людина 3 особливими можливостями, звужують можливості їі самореалізації. Суть проблеми полягає у нерівності можливостей при проголошенні рівності прав. Завданням соціального захисту на сучасному етапі стає соціальна інтеграція людей 3 особливими можливостями і допомога в усвідомленні й реалізації ними своїх невід'ємних людських прав [17].

Концепція повноцінної інтеграції осіб 3 інвалідністю в суспільство включає в себе наступні положення:

- люди с обмеженими можливостями повинні жити в звичайному середовищі і (за необхідної підтримки держави) вести повноцінне життя на рівні з звичайними громадянами.

- інваліди мають право на отримання гарантованої державної соціальної допомоги та реабілітації в звичайних та спеціалізованих закладах.

- люди с обмеженими можливостями приймають рівноправну участь у соціальноекономічному житті суспільства, включаючи реалізацію права на трудову діяльність.

- мають рівні обов'язки с іншими членами суспільства [18].

Інвалідизація пов'язана із стигматизацією, яка виражає одночасно процес, результат, причину та наслідок і є руйнівним елементом у процесі соціального впливу. Стигма впливає на соціальну ідентичність особистості та включення людини в соціальне життя та комунікацію викликає серйозні зміни в поведінці [19].

Значна кількість перешкод існує на шляху до адаптації та інтеграції осіб з обмеженими можливостями в суспільство. У всесвітній доповіді щодо інвалідів [20] окреслені основні бар'єри та обмеження, пов'язані с інвалідністю:

1. Неадекватні заходи політики і стандарти. При розробці політики не завжди врахову- 
ються потреби людей 3 інвалідністю, або не застосовуються на практиці існуючі заходи політики і стандарти.

2. Негативне відношення. Упередження та забобони сприяють утворенню бар'єрів на шляху до освіти, трудової занятості та участі у соціальному житті.

3. Недолік реабілітаційних послуг і проблеми $з$ їх наданням. Гострий дефіцит реабілітаційних послуг, слабка координація відомств, недостатнє кадрове забезпечення та низький рівень професійної підготовки негативно позначаються на якості, доступності та адекватній соціальній допомозі інвалідам.

4. Недостатнє фінансування. Ресурсів, виділених на здійснення заходів соціальної політики часто недостатньо або вони не ефективно залучені.

5. Відсутність доступності. Більшість будівель, транспортних систем та інформації не $\epsilon$ доступною для всіх. Відсутність доступу до транспорту для багатьох інвалідів $\epsilon$ поширеною причиною відмови від пошуку роботи або фактором.

Заслуговує на увагу той факт, що поряд із поняттям «інвалід», «інвалідність» використовуються у науковій літературі і практичній роботі такі дефініції, як «люди з особливими потребами», «люди з обмеженими фізичними можливостями», «люди $з$ функціональними обмеженнями», «люди 3 інвалідністю», «люди з обмеженнями життєдіяльності». Тривалий час слово «інвалід» вживалося разом 3 такими поняттями, «неповноцінна людина», «дефектна людина». Це свідчило про низький соціальний статус інвалідів, відображало негативне ставлення в суспільстві до цієї категорії осіб і формувало внутрішню та зовнішню картину світу людей 3 даним статусом. Наразі щодо таких людей застосовують іноземні терміни «abled people» або «people with abilities», тобто людьми, які мають здібності, і потребують особливих умов для їх розвитку, вітчизняні ж науковці використовують термін «люди 3 інвалідністю» та «люди з обмеженнями життєдіяльності».

Висновки та перспективи подальших досліджень. Таким чином, дослідження питання осіб з обмеженими можливостями $є$ надзвичайно важливим. Від того, як піклується держава про таких осіб, можна зробити висновки про ступінь iї соціально-економічного розвитку та від цього залежить не тільки особистий рівень життя окремо взятої особи з фізичними вадами, але й нації в цілому.

Наразі зустрічається декілька підходів до розуміння інвалідності. Але згідно наукових досліджень буде розглядатися соціально- трудова модель адаптації осіб з інвалідністю, які $є$ важливими учасниками суспільного процесу поділу праці, беручи участь в соціальній i виробничій життя. Люди 3 обмеженими можливостями щодня, у багатьох компаніях і установах, доводять свою професійну цінність. Вони $є$ рушійною силою розвитку і успіху багатьох підприємств, в яких вони зосереджені на своїй роботі і можливості, що відрізняє їх від «звичайних» людей, а так само це можливість працювати на посадах, які не обмежують їх діяльність, дають можливість займатися своїми компетенціями, удосконалювати навички, досвід і перш за все дають можливість для самостійних і вільних дій. Все завдяки адаптації робочого місця до вимог в результаті інвалідності, мова про які піде в подальших дослідженнях.

\section{Література}

1. Большая медицинская энциклопедия. Т. 2. Москва, 1959. 316 с.

2. Справочник по врачебно-трудовой экспертизе. Москва, 1972. С. 7 - 8.

3. Генеральная Ассамблея ООН. Пекинская декларация и платформа действий о правах инвалидов (2000). URL: https://www.un.org/womenwatch/daw/beijing/pdf/ BDPfA\%20R.pdf

4. Андрєєв В. С. Право соиіального забезпечення в СРСР: підручник. Москва: Юрид. лит., 1987. 352 с.

5. Сорокин Ю. Словарь русского языка XVIII века: в 14 вып. URL: http://febweb.ru/feb/s118/slov- abc/

6. Холостова Е., Дементьева Н. Социальная реабилитация. Москва: Изд-которговая корпорация «Дашков и К», 2002. С.46 - 48.

7. Безпалько О. В., Братусь I. В., Лях Т. Л. Соціальна робота 3 людьми 3 особливими потребами. Практична психологія та сочіальна poбота. 2002. № 6. С. 33-46.

8. Мартыненко А. В. Основы сочиальной медицины: учебник для СПО. Москва: Издательство Юрайт, 2018. 375 с.

9. Демографический энщиклопедический словарь. Гл. ред. Д. И. Валентей. Москва: Сов. энцикл., $1985.608 \mathrm{c}$.

10. Чуксіна В. В. Комісаров Н. Н. Дискримінація за ознакою інвалідності в трудових відносинах. Право $і$ законодавство. Звістки Іркутської державної економічної академії. 2015. T.25. № 1. C.126 - 134.

11. Лукашевич М. П., Мигович I. І. Теорія і методи сочіальної роботи: навч. посіб. 2ге вид. Київ: МАУП, 2003. 168 с. 
12. Котова Л. В. Правове регулювання праці осіб з інвалідністю. Юридичний вісник. Повітряне і космічне право. 2017. № 3. С. 85-90.

13. Єлагін В. П., Артюх С.О. Розробка ефективної моделі соціальної підтримки осіб 3 обмеженими фізичними можливостями в соціальній державі. Теорія та практика державного управління. 2010. Вип. 4. С.125-131.

14. Украйнський тлумачний словник. Укл. та гол. ред. Вячеслав Бусел. Київ; Ірпінь: Перун, 2016. 1692 с.

15. Байда Л. Інвалідність та суспільство: навч. посіб. Л. Байда, О. Красюкова. Київ, 2011. $184 \mathrm{c}$.

16. Финзен А. Психоз и стигма. Пер. с нем. И.Я. Сапожниковой. Москва: Алетейя, 2001. $216 \mathrm{c}$.

17. Шурма I. М. Проблеми інтеграції людей $з$ обмеженими можливостями в суспільство. Державне будівниитво. 2013. № 1. URL: http://nbuv.gov.ua/UJRN/DeBu_2013_1_39.

18. Похвощєв А. В. Методологічні основи професійної реабілітації та сприяння зайнятості людей 3 обмеженими можливостями здоров'я. СВIT (Модернізачія. Інноващії. Розвиток). 2017. Т.8. №2. С.330-336

19. Гусак Н. Соціальна реабілітація: підходи до визначення поняття. Соціальна політика та соиіальна робота. 2008. №1. С. 103-114.

20. Всесвітня доповідь щодо інвалідності. Мальта, 2011. С. 9-11. URL: http://www.who.int/disabilities/world_report/2011/

\section{References}

1. Great medical encyclopedia. (1959). T. 2. Moscow, 316.

2. Handbook of medical and labor expertise. (1972). Moscow, 7-8.

3. UN General Assembly. Beijing Declaration and Platform for Action on the Rights of Persons with Disabilities (2000). Retrieved from: https://www.un.org/womenwatch/daw/beijing/pdf/ BDPfA\%20R.pdf

4. Andrє€v, V. S. (1987). The right of social security in the SRSR. Moscow: Juice lit., 352.

5. Sorokin, Yu. Dictionary of the Russian language of the 18th century: in 14th issue. Retrieved from: http://feb-web.ru/feb/s118/slov- abc /

\section{Стаття надійшла}

до редакції : 20.01.2020 p.
6. Kholostova, E., Dementyeva, N. (2002). Social rehabilitation. Moscow: Publishing corporation "Dashkov and K", 46-48.

7. Bezpalko, O. V., Bratus, I. V. and Lyakh, T. L. (2002). Social work with people with special needs. Practical Psychology and Social Work, 6, 33-46.

8. Martynenko, A. V. (2018). Fundamentals of social medicine. Moscow: Yurayt Publishing House, 375.

9. Demographic encyclopedic dictionary. (1985). Ed. D. I. Valentey. Moscow: Sov. encycl., 608.

10. Chuksina, V. V., Komissarov, N. N. (2015). Discrimination on the grounds of disability in labor relations. Law and legislation. Reports of the Irkutsk State Economic Academy, 25, 1, 126-134.

11. Lukashevich, M. P., Migovich, I. I. (2003). Theory and methods of social work. Kyiv: MAUP, 168.

12. Kotova, L. V. (2017). Legal regulation of labor of persons with disabilities. Legal Bulletin. Air and space law, 3, 85-90.

13. Yelagin, V. P., Artyukh, S. O. (2010). Development of an effective model of social support for people with disabilities in the welfare state. Theory and practice of public administration, $4,125-131$.

14. Ukrainian explanatory dictionary. (2016). Ed. V. Busel. Kiev; Irpen: Perun, 1692.

15. Baida, L., Krasyukova, O. (2011). Disability and society. Kyiv, 184.

16. Finzen, A. (2001). Psychosis and stigma. Moscow: Aleteyya, 216.

17. Shurma, I. M. (2013). Problems of integration of people with disabilities into society. State building, $1 . \quad$ Retrieved from: http://nbuv.gov.ua/UJRN/DeBu_2013_1_39.

18. Pokhvoshchev, A. V. (2017). Methodological foundations of vocational rehabilitation and employment of people with disabilities. WORLD (Modernization. Innovation. Development), 8, 2, 330-336

19. Gusak, N. (2008). Social rehabilitation: approaches to the definition. Social policy and social work, 1, 103-114.

20. World Report on Disability. (2011). Malta, 9-11. Retrieved from: http://www.who.int/disabilities/world_report/2011/

\section{Стаття прийнята}

до друку: 30.03.2021 p.

\section{Бібліографічний опис для цитування :}

Дружиніна В. Сутність поняття «інвалідність» в перспективі соціально-трудової інклюзії / В. Дружиніна, Г. Луценко, Б. Романюк // Часопис економічних реформ. - 2021. - № 1(41). - С. $15-$ 22. 